\title{
Assessment of genetic variability and character association for grain yield and its component traits in bread wheat (Triticum aestivum L.)
}

\section{Satnam Singh Nagar}

Narendra Deva University of Agriculture and Technology, Faizabad-224229 (U.P.) India Pradeep Kumar*

ICAR-Indian Institute of Wheat and Barley Research, Karnal-132 001 (Haryana), India S.R.Vishwakarma

Narendra Deva University of Agriculture and Technology, Faizabad-224229 (U.P.) India Gyanendra Singh

ICAR-Indian Institute of Wheat and Barley Research, Karnal-132 001 (Haryana), India B. S. Tyagi

ICAR-Indian Institute of Wheat and Barley Research, Karnal-132 001 (Haryana), India

*Corresponding author. E-mail-pradeeptaliyan231@gmail.com

\begin{abstract}
A study was conducted for estimating genetic variability and characters association for eleven yield components using 169 genotypes (13 parents, $78 F_{1}$ and $78 F_{2}$ ) of bread wheat through half-diallel mating design during rabi season 2012-13 and 2013-14. The genetic variability, heritability in broad sense, genetic advance, correlation coefficients and path analysis were carried out for the assessment of genotypes through eleven yield component traits namely; days to $50 \%$ flowering, days to maturity, plant height, spike length, number of effective tillers per plant, number of grains per spikelet, number of grains per spike, 1000-grain weight, biological yield per plant, harvest index and grain yield per plant. Analysis of variance showed significant differences (at $1 \%$ level of significance) for all the traits under study in both the generations $\left(F_{1}\right.$ and $\left.F_{2}\right)$. The phenotypic coefficient of variation (PCV) and genotypic coefficient of variation (GCV) were high for plant height followed by number of effective tillers per plant, biological yield per plant, grain yield per plant, while high heritability coupled with high genetic advance were recorded for plant height and spike length in both $F_{1}$ and $F_{2}$ generations, respectively. Grain yield per plant was positively and significantly associated with number of effective tillers per plant, spike length, number of grains per spike, 1000-grain weight, biological yield per plant and harvest index while significantly but negatively associated with plant height. Path analysis revealed that the traits namely biological yield per plant, number of effective tillers per plant, number of grains per spike, plant height and harvest index exhibited positive direct effects on grain yield at both phenotypic and genotypic level in both generation $\left(F_{1}\right.$ and $\left.F_{2}\right)$. These results, thereby suggests that yield improvement in breads wheats could be possible by emphasizing these traits while making selections in early generations.
\end{abstract}

Keywords: Correlation, Genetic variability, Heritability, Path analysis and Yield components

\section{INTRODUCTION}

Bread wheat (Triticum aestivum L.) is an important cereal crop having major share in food and nutritional security of the country. It stands second next to rice in production among cultivated crops and has been considered as "versatile cereal food". India's share in world wheat area is about $12.5 \%$, whereas it also contributes $12 \%$ in total world wheat production (Anonymous, 2016). In India, wheat crop is planted to an area of 30.23 million hectares and with production amounting to 93.50 million tons (Anonymous, 2017). Wheat is

\section{Article Info}

DOI: 10.31018/jans.v10i2.1688

Received: March 5, 2018

Revised: May 9, 2018

Accepted: May 20, 2018

\section{How to Cite}

Nagar, S.S. et al. (2018). Assessment of genetic variability and character association for grain yield and its component traits in bread wheat (Triticum aestivum L.). Journal of Applied and Natural Science, 10(2): 797 - 804 
suit different crops (Banerjee et al., 2006). Yield increases may be effectively tackled on the basis of performance of yield components and other closely related traits (Singh et al., 2008). Manifestation of wheat yield fluctuates widely as a result of its interaction with the environment, because grain yield in wheat is a complexly inherited character and is the product of several contributing factors that affect it directly or indirectly (Hristov et al., 2011). The traits for which variability present should be highly heritable as the progress through selection depend on heritability, selection intensity and genetic advance of the trait. An estimate of genetic advance along with heritability is helpful in assessing the reliability of character for selection. Yield is complexly inherited character and it is dependent on several contributing traits, generally inherited quantitatively (Yadav et al., 2011). With respect to their magnitude and nature, various morphological characters differ in their inter-relationship with yield, though they show a continuous variation and are influenced by environment. The traits with high heritability exhibiting positive association with yield can be used for indirect selection for yield and will serve as an alternate mode of selection for yield improvement. When the indirect associations become complex, path coefficient analysis is the most effective mean to find out direct and indirect causes of association among the different variables. Path coefficient analysis can discriminate between the realistic (genetic effects) and inflated (environmental effects) correlations (Yadav et al. 2011). Hence, the knowledge of direct and indirect effects of different components on yield is of prime importance in selection of high yielding genotypes. Hence, in the context of yield improvement, when selecting desirable genotypes it is very important to know the nature and extent of variation present within a set of breeding material as well as the interrelationship between each yield component and grain yield and the exact contribution of each component to yield via direct and indirect effects. It is known that the improvement of the genetic architecture of yield must be based on a more intensive study of individual yield components. Among the mating designs, diallel mating is most effective for ascertaining the systematic genetic architecture of metric traits within short periods. Therefore the main objective here, was to study the extent of genetic variability, heritability, genetic advance, correlation coefficient and path analysis of yield components and their implications in the early generation selection of better genotypes for improving grain yield in wheat.

\section{MATERIALS AND METHODS}

The material for the present investigation was comprised of 13 strains/varieties of bread wheat selected on the basis of wide variability for various yield components. The salient features of these parental lines are presented in (Table 1). The experimental material consisted 13 diverse genotypes (NW 1014, NW 2036, PBW 502, PBW 343, K 8962, HI 1563, DBW 14, RAJ 3765, RAJ 4120, HP 1744, UP 2490, UP 2425 and CBW 38) of bread wheat were planted at Main Experiment Station of Narendra Deva University of Agriculture \& Technology, Kumarganj, Faizabad (U.P.) during rabi 2012-2013 for attempting crosses following $13 \times 13$ half diallel system. During off season in the year of 2013, $F_{1}$ seed of 78 crosses was planted at IARI Regional Research Station, Wellington, Tamil Nadu for generation advancement. In the next crop season (rabi 2013-2014), the final set of experimental material comprising 13 parents along with their $78 F_{1} s$ and $78 F_{2} s$ were evaluated in a randomized block design having three replications. Each genotype was planted in a single row plot of $3 \mathrm{~m}$ length with a spacing of $23 \mathrm{~cm}$ and 10 $\mathrm{cm}$ between rows and between plants in a row, respectively. All the recommended agronomic practices (recommended dose of fertilizers, irrigation, roughing) were followed to raise a good crop. The observations were recorded on five randomly selected plants in parents, 10 plants in $F_{1}$ generation and 20 plants in $F_{2}$ generation for days to 50 $\%$ flowering, days to maturity, plant height $(\mathrm{cm})$, spike length $(\mathrm{cm})$, number of effective tillers per plant, number of spikelets per spike, number of grains per spike, 1000- grain weight (g), biological yield per plant $(\mathrm{g})$, harvest index $(\%)$ and grain yield per plant $(\mathrm{g})$.

The analysis of variance (ANOVA) was carried out following Panse and Sukhatme, (1967). Heritability (in narrow sense) in $F_{1}$ and $F_{2}$ generation was calculated as proposed by Crumpacker and Allard, (1962). The genetic advance as percent of mean was estimated as proposed by Robinson et al., (1949). Genotypic and phenotypic coefficient of variation was calculated by the formula given by Burton and De vane, (1953). The phenotypic correlation coefficients were calculated as suggested by Al-Jibouri et al., (1958). In path analysis; direct, indirect as well as residual effects were calculated. All the analysis work was done in Microsoft Excel as per the procedure given by Singh and Chaudhary, (1985).

\section{RESULTS AND DISCUSSION}

Genetic variability: Analysis of variance (ANOVA) showed high significant differences (at1\% level of significance) among the treatments, parents, hybrids and parents vs. hybrids for days to $50 \%$ flowering, days to maturity, plant height, spike length, number of effective tillers per plant, number of spikelets per spike, number of grains per spike, 1000- grain weight, biological yield per plant, harvest index and grain yield per plant 
Table 1. Details of genotypes used as base material for present study.

\begin{tabular}{lll}
\hline Genotype & Pedigree & Developed by \\
\hline NW-1014 & HAHN'S' & NDUA\&T, Faizabad \\
NW-2036 & BOW/CROW/BUC/PUN & NDUA\&T, Faizabad \\
PBW-502 & W-485/PBW-343/RAJ-482 & PAU, Ludhiana \\
PBW-343 & ND/1945/RAL/BB/3/YACO'S'/4/VEE\#5'S' & PAU, Ludhiana \\
K-8962 & K 7401/HD 2160 & CSAUAT, Kanpur \\
HI-1563 & MACS2496²/MC10 & IARI, Regional Station, Indore \\
DBW-14 & RAJ 3765/PBW 343 & IIW and BR, Karnal \\
RAJ-3765 & HD2402/VL631 & RAU, Durgapura \\
RAJ-4120 & PBW343/V1 & RAU, Durgapura \\
HP-1744 & Ciano/Paruta/Chilero/Garuda & IARI-PUSA, Bihar \\
UP-2490 & Not available in record & GBPUA\&T, Pantnagar \\
UP-2425 & HD2320/UP2262 & Pantnagar \\
CBW-38 & CNDO,VSA/R-143/ENTE/MEXICALI & IIWBR, Karnal \\
\hline
\end{tabular}

indicating the presence of considerable amount of genetic variability in the present set of material and further study would be meaningful (Table 2). The general mean of $F_{1}$ and $F_{2}$ crosses (Table 3 ) were greater than their corresponding parents for (spike length, number of effective tillers per plant, number of spikelets per spike, number of grains per spike, 1000-grain weight, biological yield per plant, harvest index and grain yield per plant) while lower for days to $50 \%$ flowering, days to maturity and plant height. Phenotypic coefficient of variation for all the traits studied was higher than the genotypic coefficient of variation (Table 3 ) which indicated the influence of environment in the expression of these metric traits. The highest value of phenotypic coefficient of variation (PCV) and genotypic coefficient of variation (GCV) were recorded for plant height, number of effective tillers per plant, number of grains per spike, biological yield per plant, harvest index and grain yield per plant in both $F_{1}$ and $F_{2}$ generations. The present result are supported by the findings reported by Singh et al. (2013) for days to maturityand plant height; Meena et al. (2014) for grains number per spike; Kumar et al. (2016) for harvest index; Singh et al., (2018) for grain yield and biological yield in wheat crop. Present results revealed that useful variability in progenies may be utilized while making selection of suitable genotypes on the basis of different selection parameters to improve grain yield in wheat.

Heritability and genetic advance: In the present study (Table 3 ), high heritability in narrow sense (more than $30 \%$ ) was observed for days to $50 \%$ flowering (49.60), days to maturity (30.80), plant height (48.82), spike length (32.80) and number of effective tillers per plant (42.06) in $F_{1}$ generation whereas for days to $50 \%$ flowering (38.63), plant height (47.30) and spike length (32.30) in $F_{2}$ generation. Similar findings were also reported by Singh et al. (2012) for days to maturity; Singh et al. (2013) and Meena et al. (2014) for plant height; Singh et al. (2014) for tillers per meter, 1000 grain weight and grain yield in wheat. Highest genetic advance (mare than $20 \%$ ) was recorded for plant height (26.04), spike length (20.08), number of effective tillers per plant (41.05), number of per spike (30.99), biological yield (56.08), harvest index (54.51) and grain yield (21.73) in $F_{1}$ generation whereas for plant height (26.62), spike length (20.86), effective tillers per plant (50.07), number of grains per spike (23.57), biological yield per plant (58.37), harvest index (54.11) and grain yield per plant (23.36) in $F_{2}$ generation, indicating that selection based on these traits would be effective for improvement of wheat crop. Similar findings were also reported by Singh et al. (2014) for tillers per meter, 1000 grain weight and grain yield; Singh et al., 2018 for biological yield and harvest index in wheat.

Estimates of high heritability coupled with high genetic advance of a character are more effective for making selection due to the fact that expression of these traits is controlled by additive gene action. Highest heritability along with highest genetic advance was recorded for plant height and spike length in both $F_{1}$ and $F_{2}$ generations, revealing the presence of additive and additive $\mathrm{x}$ additive type of gene effects in the expression of above traits. Highest heritability along with highest genetic advance for plant height and spike length was also reported by Singh et al. (2018). Therefore, present results indicated that useful variability in progenies developed through hybridization can be properly utilized and selection of suitable genotypes on the basis of different genetic parameters can be done to get high yield in bread wheat.

Genotypic and phenotypic correlation coefficient: The improvement of yield components and the knowledge of their association with its main component are beneficial in formulating the breeding programme. Genotypic correlation coefficients were, in general, slightly higher than the corresponding phenotypic correlation coefficient for almost all the traits and a close relationship between genotypic and phenotypic correlations for most of the traits indicating low environmental effects on the degree of association between various yield components (Table $4 a$ and $4 b$ ). The correlation coefficients were estimated between grain 
Nagar S.S. et al. / J. Appl. \& Nat. Sci. 10 (2): 797 - 804 (2018)

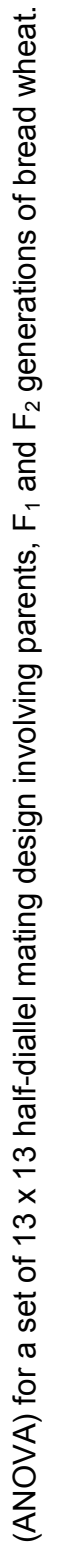

\section{更}

òำ

-

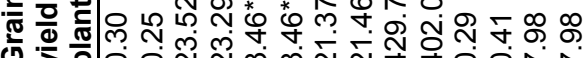

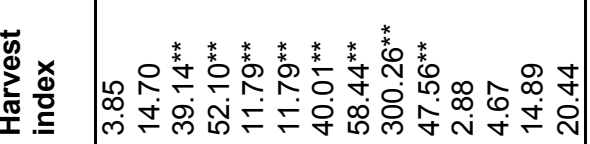

ब.

응

누의

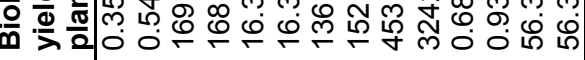

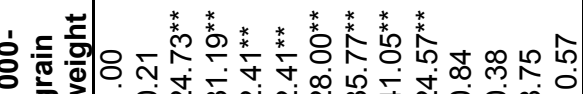

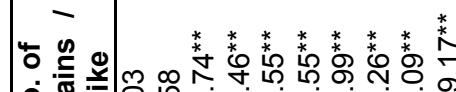

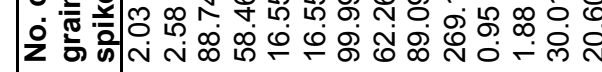

on

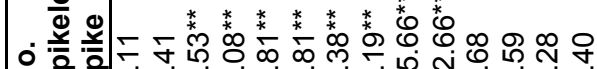
z के के 安言

政

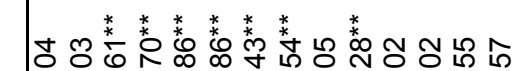

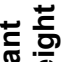

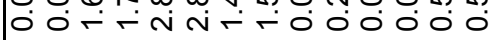

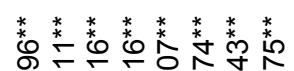

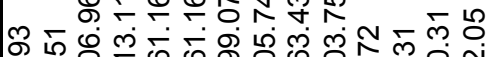

我

m- तN

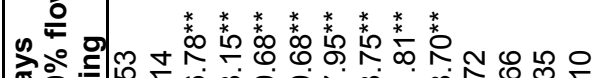
ดิ

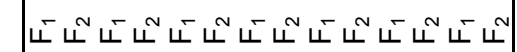

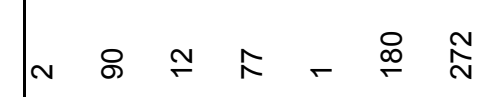

品

$\frac{\frac{\pi}{\sqrt{0}}}{\frac{\pi}{4}}$

文

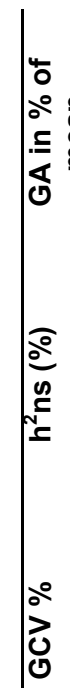

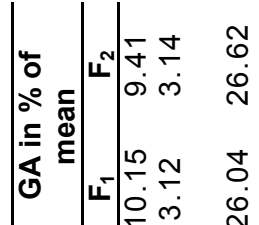

ํㅜㅇํㅇํำ

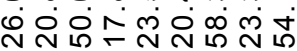

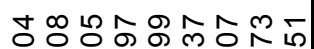

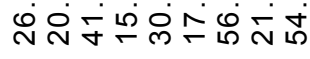

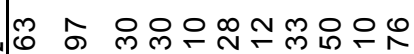

๑

น

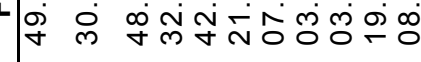

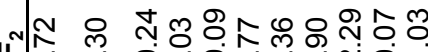

ए

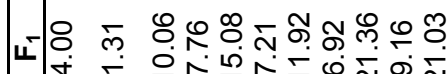

น๊

○

पे

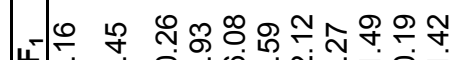

एᄂ

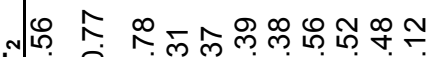

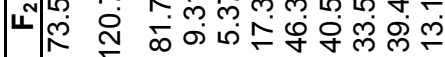

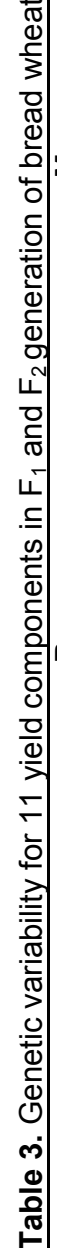

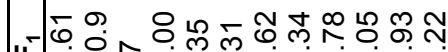

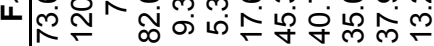

ปี 产 స

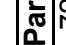

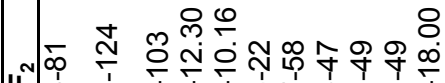

山

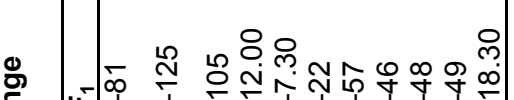

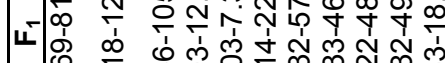

œ

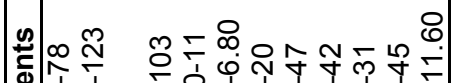

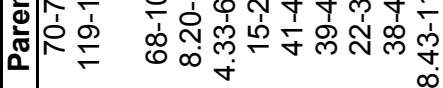

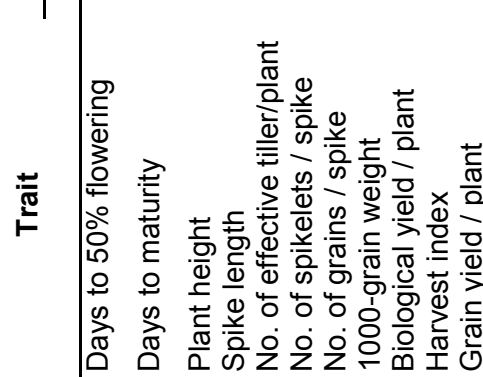




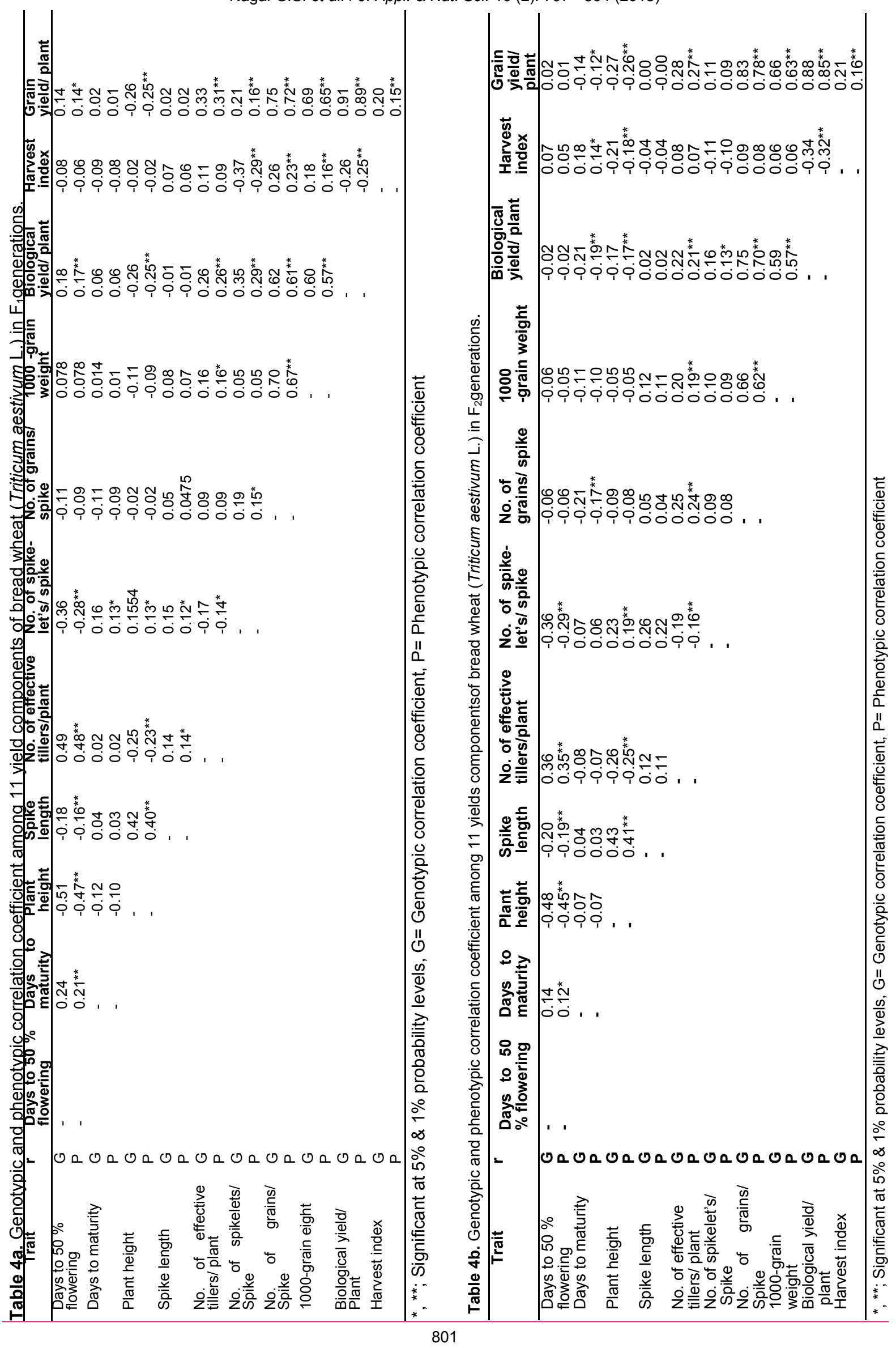


Nagar S.S. et al. / J. Appl. \& Nat. Sci. 10 (2): 797 - 804 (2018)

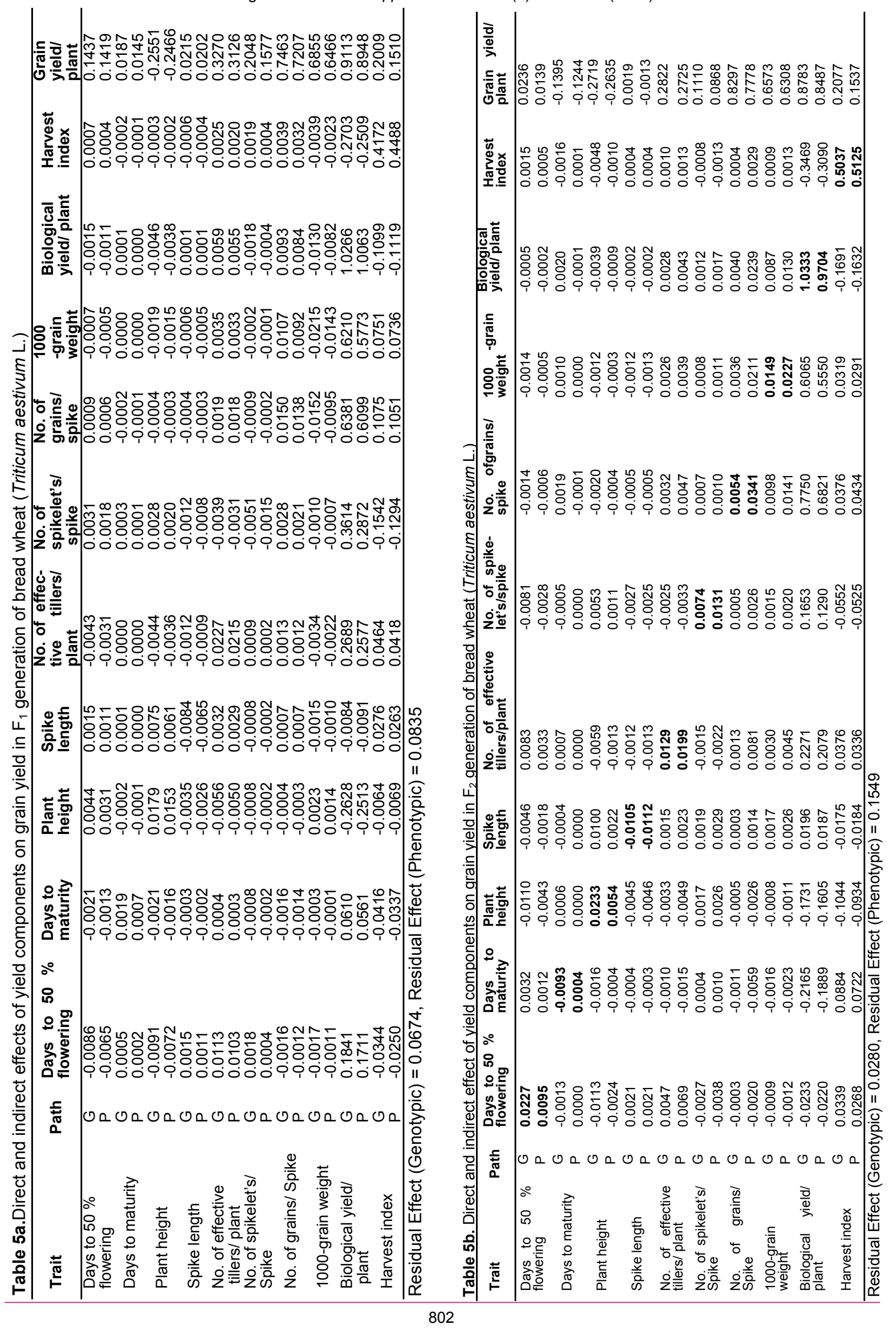


yield and its contributing traits revealed that grain yield was positively and significantly associated with number of effective tillers per plant, number of grains per spikelet, number of grains per spike, 1000 -grain weight, biological yield per plant and harvest index at both genotypic and phenotypic level in both $F_{1}$ and $F_{2}$ generations while it was significantly but negatively associated with plant height in $F_{1}$ generation and with plant height and days to maturity $F_{2}$ generation at both genotypic and phenotypic levels. The positive and significant association of number of productive tillers per plant and 1000 grain weight (Singh et al., 2014); number of productive tillers per plant, 1000 grain weight, number of grains per spike, biological yield per plant, harvest index and number of spikelets per spike with grain yield at both genotypic and phenotypic level were also earlier reported (Kumar et al., 2016) in wheat crop.

It has been observed that positive and significant association was found among number of grains per spike; biological yield per plant, spike length, number of effective tillers per plant; 1000-grain weight and biological yield per plant at both genotypic and phenotypic level in both $F_{1}$ and $F_{2}$ generations. Hence, selection for these traits would also help in improving the grain yield in this crop because these are the major components for yield.

Path coefficient analysis: The results of path coefficient indicated that biological yield per plant, harvest index, number of effective tillers per plant, number of grains per spike and plant height in $F_{1}$ generation while biological yield per plant, harvest index, number of effective tillers per plant, number of grains per spike, number of spikelet's per spike, plant height and 1000 grain weight in $F_{2}$ generation exhibited positive phenotypic and genotypic direct effects on grain yield per plant (Table $5 a$ and $5 b$ ). The number of effective tillers per plant, number of grains per spike, number of spikelet's per spike, biological yield per plant and harvest index had higher phenotypic and genotypic direct effects on grain yield per plant, thus, the correlation coefficient between grain yield and these contributing traits is real one, revealing that indirect selection for these traits would be effective in improving grain yield. The findings are in accordance with the earlier reports where direct positive effects for number of grains per spike (Khan and Dar 2010); number of tillers per plant (Narwal et al. 1999); number of grains per spike and number of tillers per plant (Meena et al., 2014); biological yield per plant and harvest index (Kumar et al., 2015); number of grains per spike and plant height (Kumar et al., 2017) has been reported in wheat.

The data indicated that different component traits had their indirect effect on grain yield per plant. Indirect contribution towards grain yield was exhibited by biological yield per plant via number of spikelets per spike, number of effective tillers per plant, 1000-grain weight and number of grains per spike in both $F_{1}$ and $F_{2}$ generations. Path coefficient analysis revealed that biological yield per plant had higher direct and indirect positive contributions towards grain yield. Hence, indirect selection for this trait would be effective in improving the grain yield. Thus, the material studied is of diverse nature and information emanated would help in designing the selection methodology which can further be used in the breeding programme for improvement of grain yield.

\section{Conclusion}

In conclusion, the present study reveals that wide genetic variability exists in wheat genotypes created through hybridization programme by half-diallel mating design. The phenotypic coefficient of variation (PCV) and genotypic coefficient of variation (GCV) were high for plant height, number of effective tillers per plant, biological yield per plant, grain yield per plant. Plant height and spike length showed a high heritability with high genetic advance in both $F_{1}$ and $F_{2}$ generations used here, indicating a significant scope for improving grain yield through selection. The high significant and positive correlations of grain yield per plant (at $<1 \%$ level of significance) with number of effective tillers per plant, number of grains per spikelet, number of grains per spike, 1000-grain weight, biological yield per plant and harvest index while significantly but negatively associated with plant height. The traits viz., biological yield per plant, number of effective tillers per plant, number of grains per spike, plant height and harvest index exhibited positive direct effects on grain yield per plant at both phenotypic and genotypic level in both generation $\left(F_{1}\right.$ and $\left.F_{2}\right)$, will help in improving grain yield through early generation selection. It is evident that genotypes developed might serve as good source of material for further breeding programme.

\section{REFFERENCES}

Al-Jibouri, H.A., Miller, P.A. and Robinson, H.F. (1958). Genotypic environment variances in an upland cotton cross of inter-specific origin. Agronomy Journal, 50: 633-637.

Anonymous (2016). Progress Report of all India Coordinated Wheat and Barley Improvement Project, 1-5 pp G. P. Singh (Ed). Directorate of Wheat Research, Karnal.

Anonymous (2017). Annual Report 2016-17, ICARIndian Institute of Wheat \& Barley Research, Karnal132001, Haryana, India.

Banerjee, J., Rawat, R.S. and Verma, J.S. (2006). Stability analysis in bread wheat (Triticum aestivum L. em. Thell) and duram wheat ( $T$. durum L.) genotypes. Indian Journal of Genetics and Plant Breeding 66 (2): 
$145-6$.

Burton, G.W. and De Vane, E.W. (1953). Estimating heritability in tall fescue (Festucaarundinacea) from replicated clonal material. Agronomy Journal, (45): 478-481.

Crumpacker, D.W. and Allard, R.W. (1962). A diallel cross analysis of heading date in wheat. Hilgardia, 32: 275-318.

Hristov, N., Mladenov, N., Kondic, S.A., Marijanovic, J.A., Jockovic, B. and Jacimovic, G. (2011). Effect of environmental and genetic factors on the correlation and stability of grain yield components in wheat. Genetika, 43(1): 141-52.

Khan, M.H. and Dar, A.N. (2010). Correlation and path coefficient analysis of some quantitative traits in wheat. African Crop Science Journal, 18(1): 9-14.

Kumar Pradeep, Singh Gyanendra, Kumar Sarvan, Kumar Anuj and Ojha Ashish (2016). Genetic analysis of grain yield and its contributing traits for their implications in improvement of bread wheat cultivars. Journal of Applied and Natural Science, 8(1): 350357.

Kumar Sandeep, Kumar Pradeep and Kerkhi S.A. (2017). Genetic analysis for various yield components and gluten content in bread wheat (Triticum aestivum L). Journal of Applied and Natural Science, 9(2): 879-882.

Meena, H.S., Kumar, D. and Prasad, S.R. (2014). Genetic variability and character association in bread wheat (Triticum aestivum). Indian Journal of Agricultural Sciences, 84 (4): 487-91.

Narwal, N. K., Verma, P. K. and Narwal, M. S. (1999). Genetic variability, correlation and path coefficient analysis in bread wheat in two climatic zones of Haryana. Agriculture Science Digest, 19(2): 73-6.

Panse, V.G. and Sukhatme, P.V. (1967). Statistical Methods of Agricultural Workers. 2nd Endorsement, ICAR Publication, New Delhi, India, pp: 381.
Robinson, H.F., Comstock, R.E. and Harvey, P.H. (1949). Estimates of heritability and degree of dominance in corn. Agronomy Journal, 41: 353-359.

Singh Girnam, Kumar Pradeep, Kumar Ravi and Gangwar, L.K. (2018). Genetic diversity analysis for various morphological and quality traits in bread wheat (Triticum aestivum L.). Journal of Applied and Natural Science, 10 (1): 24-29.

Singh Gyanendra, Kulshreshtha, N., Singh, B.N., Setter, T.L., Singh, M.K., Saharan, M.S, Tyagi, B.S., Verma Ajay and Sharma, I. (2014). Germplasm characterization, association and clustering for salinity andwaterlogging tolerance in bread wheat (Triticum aestivum). Indian Journal of Agricultural Sciences, 84: 1102-10.

Singh, G.P., Chaudhary, H.B. and Rajbir, Y. (2008). Genetics of flag leaf angle, width, length and area in bread wheat (Triticum aestivum). Indian Journal of Agricultural Sciences 78(5): 436-8.

Singh, M.K., Sharma, P.K., Tyagi, B.S. and Singh, G. (2013). Genetic analysis for morphological traits and protein content in bread wheat (Triticum aestivum L.) under normal and heat stress environments. Indian Journal of Genetics and plant breeding, 73 (3): 320324.

Singh, R.K. and Chaudhary, B.D. (1985). Biometrical Methods in Quantitative Genetic Analysis.(3rd Ed.), Kalyani Publishers, New Delhi, India.

Singh, V., Krishna, R., Singh, L. and Singh, S. (2012). Analysis of yield traits regarding variability, selection parameters and their implication for genetic improvement in wheat (Triticum aestivum L.). SABRAO Journal of Breeding and Genetics, 44 (2): 370-381.

Yadav, D.K., Giri, S.C., Vignesh, M., Vasudev, S., Yadav, A.K., Dass, B., Singh, R., Singh, N., Mohapatra, T. and Prabhu, K.V. (2011). Genetic variability and trait association studies in Indian mustard (Brassica juncea). Indian Journal of Agricultural Sciences, 81 (8): 712-6. 